\title{
Cikkismertetés: A kannabisz orvosi és rekreációs célú használata - Kérdések és válaszok
}

\author{
Article review: Medical and recreational use of cannabis - \\ Questions and answers
}

Ismertető: $\quad$ B. Erdős Márta $\square$

PTE Közösségi és Szociális Tanulmányok Tanszéke

Ismertetett cikk: Hall W, Stjepanović D, Caulkins J, Lynskey M, Leung J, Campbell G, Degenhardt: Public health implications of legalising the production and sale of cannabis for medicinal and recreational use. Lancet 2019; 10208:1580-1590. doi: 10.1016/S0140-6736(19)31789-1.

Beküldve: $\quad$ 2019.12.03.

doi: $\quad$ 10.24365/ef.v61i1.542

Kulcsszavak: kannabisz; legalizáció; rekreációs használat; orvosi alkalmazás; kockázatkezelés

Keywords: cannabis; legalization; recreational use; medical use; risk management

\section{BEVEZETÉS}

A Lancet „Drug Use” (Droghasználat) sorozatának célja a dinamikusan változó drogszcéna alakulásának áttekintése - különös tekintettel arra, hogy világviszonylatban egyre növekszik a drogok előállítása és fogyasztása. A sorozat második tanulmánya a marihuána legalizálásának hatásait igyekszik felmérni. Akár a legalizálás mellett, akár ellene érvelünk, a kiegyensúlyozott, professzionális nézőpont kialakítása és megőrzése nem könnyű feladat. E szer használatának kérdéséhez az egészségügyi vonatkozásokon túl erős gazdasági, politikai-ideológiai és kulturális szempontok kötődnek. A témával munkája során kapcsolatba kerülő szakember alapos tájékozódása az érvekről és ellenérvekről elengedhetetlen: bármilyen legyen is személyes meggyőződése ebben a kérdésben, szakmai döntéseit és kommunikációját nem vélekedésekre, hanem az elérhető tudományos tényekre, bizonyítékokra kell alapoznia. E tények azonban nem mindig egyértelműek: ellentmondásosak lehetnek, vagy az egyes érveket alátámasztó bizonyítékok köre túlságosan szúk. Különösen indokolt az óvatosság az emberi életminőséget érintő kérdésekben, mert ennek összetettsége miatt jóval nehezebb a lényegi tényezők azonosítása, vagy az oksági összefüggések pontos meghatározása.

A Lancet-ben megjelent tanulmány nemzetközi szerzőgárdája - amerikai, ausztrál és brit kutatók összefoglalják a marihuána legalizálási folyamatának főbb történéseit, főképpen az amerikai kontinensen. Számba veszik a kezdeti hatásokat, a kockázatokat, és e kockázatok kezelésének módszereit.

\section{FÖLDRAJZI, GAZDASÁGI ÉS DEMOGRÁFIAI TÉNYEZŐK}

A szerzők megállapítják, hogy a szerhasználat alakulása erősen hullámzó mintázattal jellemezhető, de összességében összefügg az egyes országok gazdasági és földrajzi helyzetével. Magas jövedelmi szint 
esetében elterjedtebb, bár az utóbbi években már az alacsony jövedelmű országokban is egyre többen fogyasztják. Kivételt képeznek ez alól az ázsiai országok, ahol a használat nem számottevő. Európai viszonylatban a közép-kelet-európai országokban a marihuána kevésbé elterjedt. Az Amerikai Egyesült Államokban és Kanadában is megfigyelték, hogy az életkori határok kitolódtak, a szer kevésbé kedvelt a serdülők körében, viszont egyre népszerúbb a harmincas éveikben járó felnőttek között. Mindez együttesen erős kulturális hatásokra utalhat.

\section{AZ ORVOSI CÉLÚ ÉS A REKREÁCIÓS (SZABADIDŐS) HASZNÁLAT ÖSSZEFÜGGÉSEI. KOCKÁZATKEZELÉS}

A kannabiszt az egyes amerikai államokban és másutt is (pl. Hollandiában, Németországban vagy Izraelben) alkalmazzák orvosi célokra; emellett több országban (pl. 2018 óta Kanadában és az USA egyes államaiban) a nem orvosi, rekreációs használat is megengedett. A rekreációs használat esetén a szer forgalmazását nemegyszer erős korlátozó szabályokhoz kötik (pl. Hollandiában).

A dekriminalizálás (a használat nem minősül bűncselekménynek többé) és legalizálás (a használatnak nincs törvényi korlátja) összefüggő folyamatait ezekben az országokban több oldalról közelíthetjük meg. Az első lépés lehet a megengedőbb törvénykezés, vagy az orvosi használat bevezetése. A kannabisz mindkét hatóanyaga, különösen a nem pszichoaktív CBD (kannabidiol), de a pszichoaktív THC (tetrahidrokannabinol) esetében is kimutatták, hogy bizonyos betegségeket kedvezően befolyásolhat, az olyanokat, ahol a tünetek miatt a fájdalomcsillapítás, az izomgörcsök oldása, az émelygés, hányinger csillapítása vagy a szorongás oldása, az életminőség javítása a cél. Amennyiben a pszichoaktív összetevőt, a THC-t kiküszöbölik, a terápiás hatékonyság csökkenhet. Az elvégzett vizsgálatok eredményei nem mindig szolgáltattak erőteljes bizonyítékokat, azaz nagy volt az eltérés az elvárt és a valós hatás között. A betegségek, amelyekben a kannabisz alkalmazása az elvégzett hatékonyságvizsgálatoki alapján hatékonynak vagy valamelyest hatékonynak bizonyult: a szklerózis multiplex, a krónikus, nem rák okozta fájdalom, a szorongásos tünetek (itt alacsony a vizsgálatokba bevont páciensek száma), a kemoterápiás kezelés során fellépő émelygés, hányinger csillapítása, valamint az epilepszia. A rákos megbetegedésekre és a HIV-AIDS tüneteire vonatkozó vizsgálatok száma alacsony. A depresszió esetében pedig nagyobb számú páciens bevonásával végzett, ismételt vizsgálatok sem mutattak ki erőteljes kedvező hatásokat. Az orvosi használat több fontos kérdést vet fel: Miképpen biztosítható a hatóanyag egységessége (pl. magasabb CBD tartalom mellett alacsonyabb THC-tartalom a pszichoaktív hatások csökkentésére)? Melyek a mellékhatások, és mit tehetünk ezek kivédésére? Összehasonlítva más gyógyszerekkel, több-e az alkalmazás előnye, és kevesebb-e a káros mellékhatás? Amennyiben a szer legálissá válik, miképpen befolyásolja ez az öngyógyító törekvéseket a lakosság körében? Hogyan hat a kannabisz azokban az esetekben, amikor a beteg egyéb gyógyszereket is szed? A kérdések megválaszolásához minden bizonnyal további kutatásokra lesz szükség.

Több, a szerzők által idézett tanulmány hangsúlyozza a szer biztonságos voltát, egyrészt az orvosi alkalmazás esetében a túladagolás minimális veszélyeit, másrészt az alkohollal, a dohányzással szemben rekreációs célú használatának összességében alacsonyabb kockázatát. A káros hatásokat illetően fontos megjegyezni, hogy különösen az állandó, intenzív használat során várható ezek megjelenése. Kutatások szerint a kannabisz használata megnövelheti a pszichotikus epizódokii kockázatát, és erős összefüggést mutat a bronchitis kialakulásával, csakúgy, mint a dohányzás. Az intenzív használat hiperemezist (erős hányást, hasi fájdalmat) okozhat, vagy akár (nagyon ritkán) szív- érrendszeri problémákat eredményez. Várandós nők esetében a gyermek születési súlya alacsonyabb lehet. Bár a marihuána füstje tartalmaz rákkeltő anyagokat, nem növelte meg a tüdőrák kockázatát, valószínúleg azért, mert a használat nem olyan intenzív, mint ami a dohányzásnál megfigyelhető. A szer viszonylag alacsony arányban vált ki függőséget: míg a kipróbálást követő, rendszeres használat a listavezető dohány-

\footnotetext{
i Kontrollcsoportot is bevonó, a vizsgálati személyeket a véletlen mintavétel alapelvei szerint beválogató

ii A lelki működés súlyos, a valóságészlelést befolyásoló átmeneti zavara
} 
zás esetében 32\%, az alkoholnál 15\%, addig a kannabisznál csupán 9\%, ami azonban megnövekszik a gyakran ismétlődő szerhasználat és a magas THC-tartalmú szerek fogyasztása esetében.

Részben még megválaszoltalan kérdéseket vet fel a serdülőkori használat. Könnyebben alakul ki függőség, megfigyelhetők mentális zavarok, kognitív károsodás - ám az oksági viszony természete nem világos (azaz lehet, hogy nem a szer okozza ezeket, hanem a szerhasználat e zavarok következménye). A kockázatok miatt a serdülők számára hatékony, főképpen a társas készségeket fejlesztő, a családi élet minőségét javító prevenciós programokat kell szervezni - ezekre mindenképpen szükség van, hiszen a többi szerhasználati zavar és viselkedési függőség kockázatát is csökkentik. Lényeges megemlíteni, hogy a valamikor népszerû kapudrog-elmélet - ezt a Lancet szerzői nem tárgyalják - újabban ismét előtérbe került. Az elmélet szerint adott pszichoaktív szer használata megnövelheti egy másik, akár jóval veszélyesebb szer használatának valószínűségét. Egyes vizsgálati eredmények arra utalnak, hogy a THC fogékonyabbá tesz főként az alkohol és a nikotin későbbi használatára. (National Institute on Drug Abuse)

Bár az orvosi célú alkalmazás több országban engedélyezett, a használat kontrollja nem volt különösebben erős, így a kétféle szerhasználó csoportot nem lehetett mindig egyértelműen megkülönböztetni, és az alkalmazott szerek sem tartalmazták a hatóanyagokat azonos koncentrációban. (Az Európában és Amerikában használt kannabisz THCtartalma az utóbbi évtizedek során 5\%-ról 15\% fölé emelkedett.) A rekreációs használat legalizálása melletti erőteljes érvként az szolgált, hogy míg maga a kriminalizálás aránytalan adófizetői terheket jelent a büntetés-végrehajtási költségek miatt, addig a legalizálással jövedéki adó nyerhető. A legalizálás lehetővé teszi ellenőrzött minőségű termékek előállítását és forgalmazását. Komoly dilemmát jelent ilyenkor a fogyasztói ár megállapítása: ha nagyon alacsony, akkor ösztönöz a használatra, ha pedig magas, akkor megnöveli az ellenőrizetlen, gyakran szennyezett, illegálisan előállított és forgalmazott, veszélyes termékek használatát. A szer kiváltotta függőség viszonylag ritka, mind az alkohollal, mind a nikotinnal összehasonlítva a kannabisz kevesebb orvosi problémát okoz. Így tehát azoknak a kezelése, akiknél a kannabisz használata problémássá válik, relatíve kisebb terhet jelent az egészségügy számára (a szerzők itt a Global Burden of Disease, Globális Betegségteher Vizsgálat megállapítását idézik). A kialakuló függőség leginkább pszichoterápiával kezelhető.

Ugyanakkor a kannabiszhasználóknál a társas életben, sőt társadalmi szinten sem tapasztalható olyan negatív hatás, mint az alkohol esetében: így például a kannabiszt legalizáló amerikai szövetségi államokban összességében nem nőtt a halálos kimenetelű közlekedési balesetek száma.

\section{TANULSÁGOK A HAZAI SZAKEMBEREK SZÁMÁRA}

A legalizálás melletti döntés a várható kockázatok kezelésére vonatkozóan mindenkor nagyon felelős hozzáállást és pontos ismereteket, sőt új technikákat követelhet meg. Itt csupán egyetlen, jól behatárolható példán keresztül szemléltetjük a kérdés jelentőségét: fontos tudni arról, hogy a kognitív funkciók romlása - ami a közlekedésben és másutt a veszélyes helyzetek kezelését befolyásolja - éppen a THC-koncentráció csökkenésének kezdetén a legmagasabb. Az esetleges legalizálás előtt ezért ki kell dolgozni a közúti ellenőrzés megfelelő módszereit, amelyek nem a szer koncentrációját, hanem a kognitív képességekre gyakorolt hatását mérik. A példából látható, hogy a legalizálás nem csupán a jogi szabályozás módosítását jelenti, hanem változásokat hoz létre olyan átfogó rendszerekben, mint a közlekedés, az egészségügy, az oktatás és a munka világa.

A Lancetben közölt tanulmányból láthattuk, hogy az orvosi alkalmazás, de főként a rekreációs használat felvet néhány, még megoldatlannak tűnő kérdést. Ott, ahol a legalizálás megtörtént, szélesebb körben nyílik mód a tapasztalatok összegyújtésére és elemzésére. Miképpen hat a kannabisz legalizálása a többi szer használatának 
alakulására hosszabb távon? Milyen kockázatokat sikerül kiküszöbölni, és milyen újabb kockázatok jelentkeznek? Miképpen változnak ezek a kockázatok az eltérő kultúrákban, társadalmakban? A szer kémiája, hatása egy dolog; de ott van még a szer használója, és a használat módja, társadalmi-kulturális környezete. Fontos kiemelni, hogy a legalizálás folyamata aligha fordítható vissza, mert e lépéssel megteremtődnek egy új iparág alapjai. Bármely ilyen, gyakorlatilag végleges döntés esetében indokolt az óvatosság, a várható hatások körültekintő és hosszú távú elemzése - az adott társadalmi-kulturális környezetre vonatkoztatva. 